\title{
Strategi Think-Talk-Write (TTW) dan Kemampuan Membaca Pemahaman Teks Ekposisi Siswa Tunagrahita Ringan
}

\author{
Widya Nindi Sari, Sudarsini, Eka Pramono \\ Universitas Negeri Malang \\ E-mail: widyanindisari@gmail.com
}

\begin{abstract}
Abstrak:membaca pemahaman adalah salah satu aspek berbahasa yang sangat penting dikuasai oleh siswa tunagrahita ringan. Membaca pemahaman lebih difokuskan pada keterampilan menguasai dan memahami isi bacaan. Kemampuan membaca pemahaman siswa akan terlihat jika dikaitkan dengan penguasaan jenis teks bacaan tertentu, salah satunya adalah jenis teks eksposisi. Untuk dapat meningkatkan kemampuan membaca pemahaman siswa dapat digunakan suatu strategi pembelajaran yaitu Think-Talk-Write (TTW). Tujuan dalam peneilitian ini adalah mengetahui perbedaan kemampuan membaca pemahaman teks eksposisi siswa tunagrahita ringan sebelum dan sesudah diberikan strategi Think-Talk-Write (TTW) serta mengetahui pengaruh penerapan strategi Think-Talk-Write (TTW) terhadap kemampuan membaca pemahaman teks eksposisi siswa tunagrahita ringan kelas VII di SMPLB Negeri Malang. Metode dalam penelitian ini adalah Quasi Experiment dengan design time series design. Hasil penelitian menunjukkan nilai rata-rata yang diperoleh saat pre-test sebesar 43, sedangkan nilai ratarata post-test meningkat menjadi 74 . Berdasarkan penelitian yang sudah dilaksanakan dapat disimpulkan bahwa penggunaan strategi Think-Talk-Write (TTW) memiliki pengaruh dalam meningkatkan kemampuan membaca pemahaman teks eksposisi pada siswa tunagrahita ringan.
\end{abstract}

Kata kunci: Tunagrahita ringan; membaca pemahaman; Think-Talk-Write (TTW)

\begin{abstract}
: reading comprehension is one of the most important aspects of language competence of mild intellectual disability students. Reading comprehension is more focused on mastering skills and understand reading content. The students reading comprehension skills will be seen when associated with the mastery of certain types of text, one of which is exposition text. Due to improve students' reading comprehension ability, we can use a learning strategy that is Think-Talk-Write (TTW). The purpose of this research is to know the difference of reading comprehension ability of expository text for mild intellectual disability students before and after being given the Think-Talk-Write (TTW) strategy and to know the effect of the application of Think-Talk-Write (TTW) strategy to the reading comprehension expository text for mild intellectual disability students in the Grade VII of SMPLB Negeri Malang. The method in this research is Quasi Experiment method with time series design. The results showed that the average value obtained during the pre-test is 43 , while the average post-test value increased to 74 . Based on the research outcome it can be concluded that the use of Think-Talk-Write (TTW) strategy has an effect in improving reading comprehension expository text for mild intellectual disability students.

Keyword: mild intellectual disability, reading comprehension, think-talk-write (TTW)
\end{abstract}

Membaca merupakan kemampuan pemahaman ide atau gagasan baik tersirat maupun tersurat. Keterampilan membaca adalah salah satu aspek penting dalam berbahasa yang harus dikuasai oleh semua siswa, selain kemampuan berbicara, menulis, menyimak dan mendengarkan. Dalam memperoleh informasi yang ditampilkan dalam bahasa tulis dibutuhkan suatu keterampilan khusus, yaitu dengan membaca pemahaman. Membaca pemahaman adalah suatu proses dalam memperoleh sebuah makna yang juga mengaitkan pengetahuan serta pengalaman, memahami detail isi bacaan yang telah dibacanya serta menguasai isi bacaan tersebut (Kurniawan: 2014). Membaca pemahaman lebih difokuskan pada keterampilan menguasai dan memahami isi bacaan. Kemampuan membaca pemahaman siswa akan terlihat jika dikaitkan dengan penguasaan jenis teks bacaan tertentu, salah satunya adalah jenis teks eksposisi. Teks eksposisi yaitu teks yang berisi tentang tulisan atau pokok pikiran yang bisa memperluas pandangan atau pengetahuan seseorang yang membaca (Janah: 2014). Tunagrahita ringan adalah mereka yang berada di dalam kelompok yang adaptasi sosial dan tingkat kecerdasan terhambat, tetapi kelompok tersebut memiliki kemampuan untuk berkembang dalam penyesuaian sosial, kemampuan bekerja, serta pelajaran akademik (Putri, 2012). Anak tunagrahita ringan adalah anak yang memiliki IQ 70-50. Salah satu kesulitan belajar anak tunagrahita ringan adalah membaca pemahaman. Kesulitan membaca pemahaman ini akan berdampak pada keterlambatan proses pembelajaran. Penyebabnya adalah anak tunagrahita ringan minim dalam mengikuti pelajaran secara baik serta cenderung lamban.

Pada kenyataannya tingkat membaca pemahaman anak tunagrahita ringan pada teks eksposisi di SMPLB Negeri Malang masih sangat rendah. Ada beberapa faktor yang menjadi penyebab rendahnya kemampuan.membaca pemahaman pada teks eksposisi tersebut. Selain karena IQ mereka yang rendah juga tidak adanya strategi pembelajaran yang selama ini 
diterapkan untuk meningkatkan kemampuan.membaca pemahaman. Salah satu bentuk strategi pembelajaran yang bisa diaplikasikan adalah Thik-Talk-Write (TTW). Strategi pembelajaran Think Talk Write (TTW) dapat mengajak siswa untuk berpikir, berbicara, serta menuliskan berkenaan dengan suatu topik (Wirawan: 2016). TTW merupakan strategi pembelajaran yang bisa meningkatkan aktifitas komunikasi serta bertanya antar siswa. Sintak dari strategi Think-Talk-Write (TTW) diawali pada tahap berpikir (think) yaitu setelah membaca teks bacaan siswa membuat catatan-catatan kecil yang berisi ide-ide ataupun penyelesaian masalah yang ada dalam teks, berbicara (talk) pada tahap ini siswa belajar untuk mengemukakan pendapatnya di forum diskusi dan melatih kemampuan berkomunikasi dengan orang lain, serta tahap menulis (write) yaitu siswa menuliskan pengetahuan atau hal-hal baru yang diperolehnya menggunakan bahasa sendiri.

\section{METODE}

Jenis penelitian ini yaitu penelitian eksperimen semu (Quasi Experiment). Dikatakan sebagai penelitian semu dikarenakan perlakukan yang diterapkan pada subjek penelitian tidak dikendalikan sepenuhnya. Penelitian yang digunakan yaitu quasi eksperiment dengan bentuk time series design. Desain penelitian menggunakan satu kelompok dan tidak memerlukan kelompok kontrol. Saat dilakukan penelitian, sebelum diberikan perlakuan atau treatment kelompok diberikan pretest sebanyak empat kali. . Hasil pretest yang baik adalah $\mathrm{O}_{1}=\mathrm{O}_{2}=\mathrm{O}_{3}=\mathrm{O}_{4}$ serta perlakuan (treatment) yang baik adalah $\mathrm{O}_{5}=\mathrm{O}_{6}=\mathrm{O}_{7}=\mathrm{O}_{8}$ (Sugiyono: 2015).

Teknik pengumpulan datanya yaitu dalam bentuk tes tulis. Pre test dilakukan sebelum diberikan perlakuan dan post test dilaksanakan setelah diberikan perlakuan. Pre-test dilakukan sesuai dengan instrument yang telah dibuat. Untuk mengetahui kejelasan dan kestabilan kelompok sebelum diberikan treatment, maka pre test diberikan sebanyak empat kali. Sedangkan posttest dilaksanakan untuk melihat dan mengevaluasi pengaruh strategi Think-Talk-Write (TTW) terhadap kemampuan membaca pemahaman teks eksposisi siswa. Analisis datanya yaitu analisis statistic inferensial non parametris. Statistik non parametris tidak menuntut terpenuhi banyak asumsi, misalnya data yang akan dianalisis tidak harus berdistribusi normal (Sugiyono: 2015). Uji hipotesis yang sesuai untuk penelitian ini adalah uji t.

\section{HASIL DAN PEMBAHASANAN}

\section{Hasil}

Kemampuan awal siswa (pre test) sebelum menggunakan strategi Think-Talk-Write (TTW) yang didapat dari hasil tes pada awal dilakukan penelitian.
Kegiatan pre test dilaksanakan selama empat hari yakni pada hari Senin-Kamis tanggal 5-8 Maret 2018. Kegiatan pre test dilakukan dengan tujuan untuk mengetahui kemampuan membaca pemahaman teks eksposisi siswa sebelum diberikan suatu perlakuan (treatment). Pada saat pelaksanaan pre test terlebih dahulu siswa diberikan kegiatan pembelajaran berupa peneliti membacakan contoh teks eksposisi. Saat mulai mengerjakan beberapa siswa mengalami kesulitan sehingga membutuhkan bantuan peneliti untuk menjawab soal yang diberikan. Berikut hasil yang dari pre-test yang diperoleh siswa.

Berdasarkan data pada tabel bisa diketahui rata-rata nilai pre test kemampuan awal membaca pemahaman teks eksposisi yakni 2 siswa mendapat rentang nilai 0-38 dan 3 siswa mendapat rentang nilai 40-55. Nilai skor rata-rata pre-test siswa adalah 43 sehingga dapat dikatakan bahwasannya kemampuan membaca pemahaman teks eksposisi siswa pada kegiatan pre test masuk pada kategori kurang.

Kemampuan akhir siswa (post test) setelah menggunakan strategi Think-Talk-Write (TTW) yang dilaksanakan selama empat hari yakni pada hari Senin-Kamis tanggal 19-22 Maret 2018. Kegiatan post test dilakukan dengan tujuan untuk mengetahui kemampuan membaca pemahaman teks eksposisi siswa sesudah diberikan suatu perlakuan (treatment). Sesudah diberikan perlakuan siswa semangat serta antusias ketika mengerjakan soal post test. Bahkan hampir tidak ada pertanyan yang diajukan siswa kepada peneliti.

Berdasarkan data pada tabel bisa diketahui rata-rata nilai pre test kemampuan awal membaca pemahaman teks eksposisi yakni 1 siswa mendapat rentang nilai 56-65, 2 siswa mendapat rentang nilai 66-79 dan 2 siswa mendapat rentang nilai 80-100. Nilai skor rata-rata pre test siswa adalah 74 sehingga bisa dikatakan bahwasannya kemampuan membaca pemahaman teks eksposisi siswa pada kegiatan post test masuk pada kategori baik.

Setelah mengetahui hasil nilai pre test dan post test, selanjutnya dilakukan rekapitulasi yang tujuannya untuk mengetahui ada tidaknya peningkatan kemampuan membaca pemahaman teks eksposisi setelah menggunakan strategi Think-Talk-Write (TTW).

Adapun diagram batang hasil nilai pre test dan post test kemampuan membaca pemahaman teks eksposisi sebelum dan sesudah menerapkan strategi Think-Talk-Write (TTW). Berdasarkan diagram batang di atas bisa dikatakan bahwasannya nilai ratarata pre test yang diperoleh siswa lebih rendah dari nilai rata-rata dari post test. Perbedaan nilai rata-rata antara pre test serta post test menunjukkan bahwa adanya perbedaan kemampuan membaca pemahaman teks eksposisi siswa tunagrahita ringan sebelum dan sesudah diberikan suatu perlakuan (treatment) yaitu 
strategi Think-Talk-Write (TTW).

Penerapan strategi think-talk-write (TTW) dalam meningkatkan kemampuan membaca pemahaman teks eksposisi siswa tunagrahita ringan kelas VII SMPLB Negeri Malang. Proses pembelajaran dimulai dengan peneliti menyampaikan tujuan pembelajaran. Kemudian dilanjutkan dengan pembagian kelompok yang mana masing-masing kelompok beranggotakan 3 orang. Peneliti selanjutnya memberikan lembar kerja pada siswa dan petunjuk pelaksanaannya. Siswa harus mencatat kata-kata sulit serta hal-hal yang belum mereka pahami pada teks bacaan. Siswa selanjutnya berdiskusi bersama anggota kelompok untuk menyelesaikan soal yang telah dibagikan peneliti. Setelah selesai mengerjakan lembar kerja masingmasing kelompok mempresentasikan di depan kelas yang mana masing-masing anggota kelompok secara bergantian membacakan hasil diskusi kelompoknya. Setelah semua selesai presentasi masing-masing siswa mengkonstruksi sendiri pengetahuan yang diperolenya menggunakan bahasa sendiri. Dilanjutkan dengan peneliti membahas kata-kata sulit yang sudah ditulis siswa dan melakukan tanya jawab. Pada akhir pembelajaran, peneliti menyimpulkan tentang pembejaran yang telah dilakukan.

\section{Pembahasan}

Kemampuan membaca pemahaman teks eksposisi siswa tunagrahita ringan sebelum diberikan perlakuan (treatment) pada siswa tunagrahita ringan kelas VII di SMPLBN Malang dengan jumlah 5 siswa. Pre-test diberikan untuk mengetahui sejauh mana kemampuan membaca pemahaman teks eksposisi siswa. Kondisi awal siswa sebelum diberikan perlakuan, kemampuan membaca pemahamannya masih kurang. Siswa cenderung bingung dengan soal yang dibagikan peneliti. Saat akan menjawab soal pada teks bacaan siswa membacanya berulang-ulang dan membolakbalikkan kertas. Siswa juga saling bertanya dengan temannya.

Berdasarkan hasil pre test diketahui bahwa kemampuan membaca pemahaman teks eksposisi siswa tunagrahita ringan kelas VII SMPLB Negeri Malang sebelum menggunakan strategi ThinkTalk-Write (TTW) yaitu sebanyak 40\% siswa gagal dan 60\% kurang. Membaca pemahaman adalah proses pemerolehan makna yang juga mengaitkan pengetahuan serta pengalaman, memahami detail isi bacaan yang dibacanya dan menguasai isi bacaan tersebut (Kurniawan: 2014).

Menurut Burn, Roe dan Ross dalam Dalman (2017) dalam meningkatkan kemampuan membaca pemahaman, setidaknya guru perlu membina lima faktor pendukung pemahaman, yaitu: (1) Potensi skema pembaca, (2) Potensi mengingat, (3) Perspektif pembaca, (4) Kemampuan berpikir, 5) Aspek afektif.
Kemampuan membaca pemahaman teks eksposisi siswa tunagrahita ringan sesudah diberikan perlakuan (treatment) yang dilaksanakan selama 4 kali selama berturut-turut pada bulan Maret 2018. Kondisi siswa tunagrahita ringan dalam membaca pemahaman teks eksposisi sesudah diberikan treatment lebih baik jika dibandingkan dengan kondisi awal sebelum diberikan perlakuan (treatment) atau dapat dikatakan kemampuan membaca pemahaman teks eksposisi siswa mengalami peningkatan. Saat mengerjakan soal post test siswa lebih semangat dan percaya diri.

Siswa hanya mengajukan sedikit pertanyaan kepada peneliti bahkan ada dua siswa yang tidak bertanya kepada peneliti. Namun juga ada siswa yang masih membutuhkan bantuan peneliti. Siswa juga dapat dengan mudah mendapatkan kata kunci pada soal sehingga saat mencari jawaban pada bacaan siswa tidak lagi membacanya dari paragraf pertama.

Berdasarkan hasil post-test diketahui bahwa kemampuan membaca pemahaman teks eksposisi siswa tungrahita ringan kelas VII SMPLB Negeri Malang mengalami peningkatan. Pernyataan ini dibuktikan melalui data yang diperoleh yaitu siswa yang berada dalam kategori cukup sebanyak 20\%, siswa yang berada dalam kategori baik sebanyak $40 \%$ dan siswa yang berada dalam kategori sangat baik sebanyak $40 \%$. Peningkatan tersebut tentunya dipengaruhi dengan penggunaan suatu strategi pembelajaran.

Menurut Ningsih (2011) Think-Talk-Write (TTW) adalah strategi pembelajaran yang bisa meningkatkan aktifitas bertanya serta komunikasi antar siswa. Alur Think-Talk-Write (TTW) diawali dari keterlibatan siswa dalam berpikir atau berbicara dengan dirinya sendiri setelah membaca suatu teks tertentu, kemudian berbicara dan berbagi ide-ide dengan temannya sebelumnya dituangkan dalam bentuk tulisan (Kuswari:2010). Strategi pembelajaran TTW dilakukan dengan membentuk kelompok dengan 3-5 anggota. Strategi pembelajaran Think-Talk-Write (TTW) merupakan strategi yang digunakan pada proses belajar. Kelebihan dari strategi Think-Talk-Write (TTW) yaitu dapat mengembangkan pemecahan yang bermakna dalam upaya memahami sebuah materi. Sehingga dengan diterapkannya strategi Think-TalkWrite (TTW) pada penelitian yaitu siswa tunagrahita ringan lebih mudah dalam memahami suatu isi bacaan.

\section{KESIMPULAN DAN SARAN}

\section{Kesimpulan}

Berdasarkan hasil analisis dan pembahasan yang telah dipaparkan pada bab sebelumnya dapat disimpulkan bahwa: penggunaan strategi ThinkTalk-Write (TTW) dapat memberi pengaruh dalam meningkatkan membaca pemahaman teks eksposisi pada siswa tunagrahita ringan kelas VII di SMPLB 
Negeri Malang dengan subjek AA, AM, AZ, D, dan R. Keadaan ini ditunjukkan dengan perubahan skor rata-rata dari pre-test (O1-O4) siswa adalah 43 dan pada skor rata-rata post-test (O5-O8) siswa adalah 74 . Dengan diperolehnya hasil rata-rata post-test siswa sebesar 74 dengan menggunakan strategi Think-TalkWrite (TTW), maka dapat dikatakan memiliki pengaruh baik terhadap kenaikan skor dalam meningkatkan kemampuan membaca pemahaman teks eksposisi pada siswa tunagrahita ringan.

\section{Saran}

Berdasarkan temuan peneliti dan kondisi lapangan penelitian, disarankan bahwa guru sebagai pendidik dapat mengoptimalkan atau memfasilitasi kemampuan yang dimiliki oleh siswa tunagrahita ringan terutama bagi anak tunagrahita ringan yang memiliki masalah pada memori dan pengolahan pemikiran. Karena penggunaan strategi Think-TalkWrite (TTW) dalam membaca pemahaman dapat diterapkan karena dapat melatih anak untuk berpikir, meningkatakan kemampuan mengingat dan menulis dengan menggunakan kata-kata sendiri sesuai dengan pengetahuan yang baru diperolehnya. Selain itu ThinkTalk-Write (TTW) dapat membantu komunikasi dan interaksi siswa yang membuat anak menjadi lebih percaya diri.

\section{DAFTAR RUJUKAN}

Burn, Paul Clay., Roe, Betty D., Ross, Elinor Parry. (2011). Teaching Reading in Today's Elementary Schools. Cengage Learning.
Janah, Nisa Miftakhul. (2014). Hubungan Minat Baca Dan Penguasaan Kosakata Dengan Kemampuan Menulis Teks Eksposisi Pada Siswa Kelas X Sma Negeri Sekabupaten Bantul. Skripsi tidak diterbitkan. Yogyakarta: Fakultas Sastra dan Seni, Universitas Negeri Yogyakarta.

Kurniawan, Muhammad Yusuf., Slamet, St.Y., \& Shaifuddin, M. (2014). Peningkatan Keterampilan Membaca Pemahaman Dengan Menggunakan Strategi Directed Reading Thinking Activity (DRTA), 1-6. DOI: DOI: http://ejournal.unp. ac.id/index.php/jupekhu

Kuswari, Usep. (2010).Model Pembelajaran Menulis dengan Teknik Think Talk Write (TTW).

Ningsih, Dwi Untari., Santosa, Slamet., \& Sugiharto, Bowo. 2011. Penerapan Strategi Pembelajaran Think Talk Write Berbasis Kontekstual Untuk Meningkatkan Keterampilan Proses Sains Siswa Kelas X-8 SMA Negeri 1 Sukoharjo Tahun Pelajaran 2010/ 2011. Jurnal Pendidikan Biologi, 3(2), 55-64. DOI:

Putri, Nadya. (2012). Efektifitas Penggunaan Media Video Untuk Meningkatkan Pengenalan Alat Musik Daerah Pada Pembelajaran IPS Bagi Anak Tunagrahita Ringan Di Sdlb 20 Kota Solok. Jurnal Ilmiah Pendidikan Khusus, 1(2), 318-328.

Sugiyono. (2015). Metode Penelitian Pendidikan. Bandung: Alfabeta.

Wirawan, I Kadek. (2016). Model Pembelajaran Kooperatif Think-Talk-Write (TTW). 